\title{
False Ceiling Design Selection in Hospitals According to the Ventilation Design and Room Type to Prevent Airborne Contamination
}

\author{
Dr. Dharmik Vaishnav, Ahmedabad, India.drdharmikv@gmail.com
}

Abstract - False ceiling design is one of the important criteria to be considered in design when a positive or negative room type and air pressure considerations are important to prevent the contamination specially in airborne contamination. If the pressure is not maintained inside the room as per the design, there are chances of spread of the contamination. One of the major reasons behind pressure loss or compromised air tightness is the design of the false ceiling. If ceiling design in inappropriate and have avoidable features like fissures or perforations in the ceiling and exposed grid system, pressure loss will be there due to lack of air tightness in the ceiling, even if the material has antimicrobial coating, it is not of much use. Unexposed grid system like concealed grid system or clip in system may also have grooves which may cause accumulation of contaminants. Monolithic or seamless ceiling is the most suitable option in such conditions and in this ceiling various options like Gypsum board, paperless Gypsum boards, Fibre cement boards, Calcium Silicate boards etc can be considered after evaluating the limiting parameters of these boards to construct a seamless ceiling. Seamless or monolithic ceiling can create a solution which can give air tightness to maintain the designed pressure of the room to avoid airborne contamination.

Keywords - Airborne contamination and false ceiling design, Hospital false ceiling design, positive and negative room pressure and false ceiling selection, seamless ceiling in hospitals.

\section{INTRODUCTION}

Selection of false ceiling in a hospital is always a choice between the aesthetics and performance. Most of the times the claims made by vendors create an illusion of satisfying both the criteria for the ceiling design. Various authorities have defined various criteria in terms of the ceiling performance but in this paper, only one criterion, infection control has been evaluated for the discussion. This criterion also has a relevance looking at current Covid 19 scenario.

When it comes to the products to be used in hospital, there are many claims for various products in terms of the performance of anti-bacterial, anti-fungal etc. but when it comes to the usage of the product in the area as per the specific area performance requirement, product suggestion or application suggestion need to be evaluated.

One of the important parameters in hospital for infection control is airborne and droplet transmission. Aerosols are particles suspended in air that can contain a variety of pathogens, including viruses, and there is ongoing debate about how to classify them. Many divide aerosols into the categories of small droplets (which some exclusively call aerosols) and large droplets, with small droplets having the potential to desiccate and form droplet nuclei that travel long distances, while large droplets do not evaporate before settling on surfaces [1]. depending upon the size, aerosols may travel distance and create a potential risk of infection.

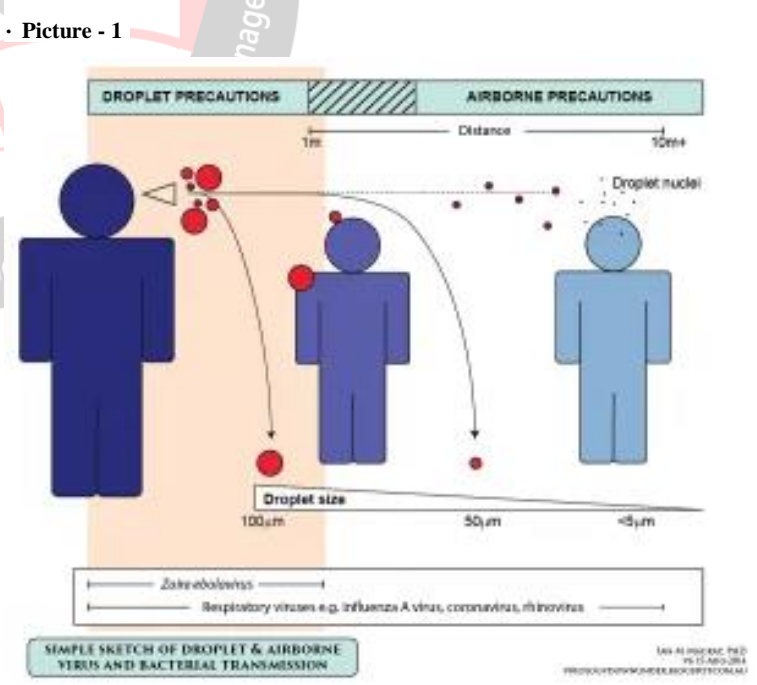

(Source : Ian M Mackay virology under blogspot.au V6 15-8-2014)

In normal breathing droplets may not travel more than one or two meter but in the case of sneezing and coughing it may travel further Coughing and sneezing can propel these large droplets much further - at least 6 meters or 18 feet [2]

Following figure explains the how droplets travel and why infection spreads. This also shows that the depending upon the size of particle and distance travelled by it decides the 
spread of the infections spread by various types of pathogens

\section{VENTILATION METHODS AND FALSE CEILING REQUIREMENTS}

After the SARS outbreak, the role of ventilation became quite prominent in terms of the control of airborne diseases. Ventilation is defined as the supply/distribution or removal of air from space by mechanical or natural means [3]. To create favourable conditions like maintenance of temperature and humidity along with the comfort and contaminants removal, ventilation is used. Ventilation in hospitals is also expected to remove the droplets nuclei efficiently, which potentially contain pathogens, so as to minimize the cross infection risk and to supply pathogen-free fresh air for breathing [4]. In various diseases, different ventilation technologies are used.

As per AIA Guidelines for the Construction of Hospitals and Health Care Facilities. 2006, an offset of pressure is kept at a level at which the difference forces air to enter the room under the door and through other leakages and prevents infectious particles from escaping. In such rooms, the sum of the mechanically exhausted air must exceed the sum of the mechanically supplied air and these rooms are called negative pressure rooms. When air pressure in the room is greater than in the adjacent corridor, it is called positive pressure room. When there is no pressure difference, it is a standard room and when design is to achieve positive and negative both the pressure, it is known as alternating rooms. Other than room types, there are many other considerations like filter type, air change rate, ventilation design, exhaust discharge locations etc which are considered in design when ventilation is used for the control of airborne infections.

In the Guidelines for the classification and design of isolation rooms in health care facilities Victorian Advisory Committee on Infection Control 2007, committee has also recommended the functional classification of the isolation of the rooms [5]

Table - 1

\section{FUNCTIONAL CLASSIFICATION OF ISOLATION ROOMS}

\begin{tabular}{|l|l|l|l|l|}
\hline & \multicolumn{1}{|c|}{ CLASS S } & \multicolumn{1}{|c|}{ CLASS N } & \multicolumn{1}{|c|}{ CLASS P } & CLASS Q \\
\hline $\begin{array}{l}\text { KEY VENTILATION } \\
\text { CRITERIA }\end{array}$ & $\begin{array}{l}\text { No air pressure } \\
\text { difference } \\
\text { between room } \\
\text { and the } \\
\text { adjacent } \\
\text { corridor }\end{array}$ & $\begin{array}{l}\text { Lower air } \\
\text { pressure in the } \\
\text { room than in } \\
\text { the adjacent } \\
\text { corridor or } \\
\text { anteroom }\end{array}$ & $\begin{array}{l}\text { Greater air } \\
\text { pressure in the } \\
\text { room than in } \\
\text { the corridor }\end{array}$ & $\begin{array}{l}\text { Lower air } \\
\text { pressure in the } \\
\text { room than in } \\
\text { the adjacent } \\
\text { corridor }\end{array}$ \\
\hline $\begin{array}{l}\text { TRANSMISSION- } \\
\text { BASED } \\
\text { PRECAUTIONS }\end{array}$ & $\begin{array}{l}\text { To prevent } \\
\text { contact or } \\
\text { droplet } \\
\text { transmission }\end{array}$ & $\begin{array}{l}\text { To prevent } \\
\text { airborne } \\
\text { transmission }\end{array}$ & $\begin{array}{l}\text { To prevent } \\
\text { transmission of } \\
\text { pathogens from } \\
\text { the outside } \\
\text { environment to } \\
\text { profoundly } \\
\text { immuno- } \\
\text { compromised } \\
\text { persons }\end{array}$ & $\begin{array}{l}\text { To prevent } \\
\text { airborne } \\
\text { transmission }\end{array}$ \\
\hline EXAMPLES & $\begin{array}{l}\text { VRE, } \\
\text { gastroenteritis, } \\
\text { cutaneous } \\
\text { anthrax, } \\
\text { hepatitis A. }\end{array}$ & $\begin{array}{l}\text { Measles, } \\
\text { varicella, } \\
\text { suspected or } \\
\text { proven } \\
\text { pulmonary or } \\
\text { laryngeal } \\
\text { tuberculosis, } \\
\text { suspected } \\
\text { contact of } \\
\text { measles, } \\
\text { varicella, } \\
\text { SARS, etc. }\end{array}$ & $\begin{array}{l}\text { Prevention of } \\
\text { aspergillosis in } \\
\text { bone-manrow } \\
\text { transplant } \\
\text { recipients }\end{array}$ & $\begin{array}{l}\text { Highly } \\
\text { infectious } \\
\text { pathogens such } \\
\text { as } \\
\text { haemorrhagic } \\
\text { fevers, } \\
\text { Hantavirus } \\
\text { pulmonary } \\
\text { syndrome }\end{array}$ \\
& & & \\
& & & \\
\hline
\end{tabular}

For class $\mathrm{N}$ or negative pressure room they recommend "Ensure the room is as airtight as possible, with monolithic ceilings, well-sealed penetrations, tight fitting doors and windows, and a door grille designed for a controlled air path. Efficient sealing of the room will result in better maintenance of pressure gradients with less load on the air handling plant".

For class $\mathrm{P}$ or positive pressure room they recommend "Ensure the room is as airtight as possible, with plaster board ceilings, well-sealed penetrations, tight fitting doors and windows, and a door grille designed for a controlled air path. Efficient sealing of the room will result in better maintenance of pressure gradients with less load on the air handling plant.".

Even as per the Recommendations of CDC and the Healthcare Infection Control Practices Advisory Committee (HICPAC), recommended ceilings are smooth and free of fissures, open joints and crevices.

\section{CONTAMINANTS AND ROOM TYPES}

In a governmental hospital, Staphylococcus aureus (16.2\%) was found to be the most common organism, followed by Micrococcus luteus (13.3\%) and coagulase-negative Staphylococcus (13\%). Coagulasenegative Staphylococcus $(17.2 \%)$, followed by S. aureus $(16.8 \%)$ and M. luteus $(10.7 \%)$ were found to be the most common in a private hospital. Aspergillus spp., Penicillium spp., Rhizopus spp. and Alternaria spp. were isolated in both hospitals [6].

There are many possibilities of contaminants accumulation inside a room. Surfaces, such as carpets, potted plants and multiple-hole false ceilings are potential sources of fungal contamination. Dust might accumulate in these areas and spores may enter the patient room as contaminants on personnel's clothing [7].

Due to many factors the negative air pressure or the air tightness of the room gets compromised which may lead to the chances of spread of contamination. The main factors that broke up the negative pressure included inadequate reliability of pressure monitoring and controlling devices, strong diffuser flow directed at the door, interaction with other exhaust ventilation systems and poor airtightness of the suspended false ceiling [8].

Even as per the guidance for developing healthcare facilities to prepare for COVID patients, and is based on input from ASHE,ASHRAE Technical Committee for Healthcare and ASHRAE/ASHE Standard 170 Committee presentation ( guidance was considered personal opinion), they recommend that the negative Relative Pressure Helps Contain Contaminants [9].

The 2014 FGI Guidelines/Standard 170-2013, examples of positive pressure rooms are Operating rooms 
- Delivery rooms

- Trauma rooms

- New born intensive care

- Laser eye rooms

- Protective environment rooms

- Pharmacy

- Laboratory, media transfer

- Central Medical and Surgical Supply Clean workrooms

- Central Medical and Surgical Supply Sterile Storage

In case of breach of pressurisation, airborne contaminants may be pulled into from the adjacent areas this may lead to aseptic environment in the room with higher airborne bacteria, virus and fungi concentration.

Whereas negative pressure room examples are,

- $\quad$ ER waiting rooms

- Radiology waiting rooms

- Triage

- Toilet rooms

- Airborne infection isolation (AII) rooms

- Darkrooms

- Cytology, glass washing,

histology, microbiology, nuclear medicine, pathology, and sterilizing laboratories

- Autopsy rooms

- Soiled workrooms or holding rooms

- Soiled or decontamination room for central medical and surgical supply

- Soiled linen and trash chute rooms

- Janitors' closets

such rooms are negatively pressurized as compared to adjacent areas to prevent airborne contaminants from drifting to other areas. If negative pressure is not maintained in these rooms then it may cause unpleasant odours to migrate and it may also promote the spread of airborne contamination.

\section{FALSE CEILING MATERIAL AND DESIGN SELECTION}

These recommendations and guidelines lead to the following conclusions in terms of false ceiling material selection in above said areas.

1- False ceiling should be able to maintain the pressure without leakages

2- False ceiling should be monolithic and perforation less to avoid contamination or air leakages

There are two types of false ceiling installation options with reference to the grid selection. One is exposed grid false ceiling and the second choice is joint less ceiling. To meet above said pressure and contamination control requirements, evaluation of possible false ceiling options are 1- Grid ceiling (modular ceiling / exposed grid ceiling) 2- Joint less ceiling (monolithic / plain / seamless ceiling) [10]

Grid ceilings products can be selected from Mineral Fibre tiles, Gypsum tiles, Glasswool tiles, Metal tiles, calcium silicate tiles etc but none of the products may help in terms of airtightness of the room. Moreover, perforation in MFT, Gypsum, calcium silicate or metal tiles may also lead to problems related to pressure maintenance. Even antibacterial coating of the tiles may not be much useful as it may not help in terms of maintaining the pressure. Clip in tiles or for that matter concealed grid ceiling offers zero visibility of the gird system and non-perforated material is also available in this systems but this may also allow some dust formation inside the grooves and may not remain a hygienic condition for the hospital environment.

Figure - 2 Lay in ceiling

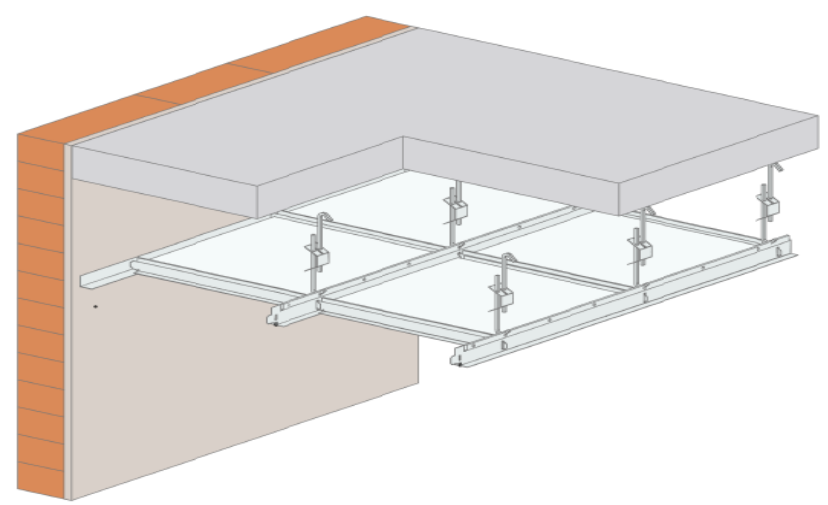

(Source - Gyproc Saint-Gobain grid ceiling specification template)

So perforated, non perforated, clip in, lay in, metal, Gypsum, MFT, Glasswool etc all kind of tiles (exposed grid ceiling) may not be the right choice for these areas due to above mentioned reasons.

\section{Figure -3 Clip in ceiling}

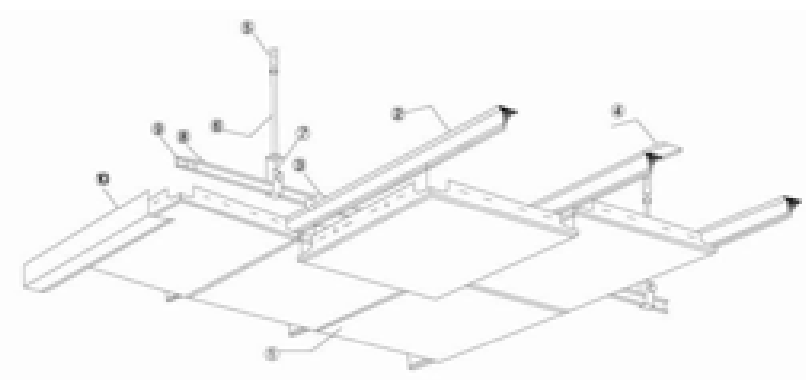

(Source - Gyproc Saint-Gobain grid ceiling specification template)

Evaluating joint less ceiling option, there are possibilities of Gypsum board, Fibre cement board, Calcium Silicate board etc which are commonly used in construction of false ceiling. Fibre cement boards and Calcium silicate boards have the issues of weight, moisture absorption 
capacity (for fibre cement boards up to $30 \%$ and for calcium silicate it ranges from 20 to $40 \%$ in various reports) as well as cracks on the surface. If these issues can be resolved then these products can be used with proper sealing in above mentioned areas.

\section{Figure -4 Joint less / Seamless ceiling}

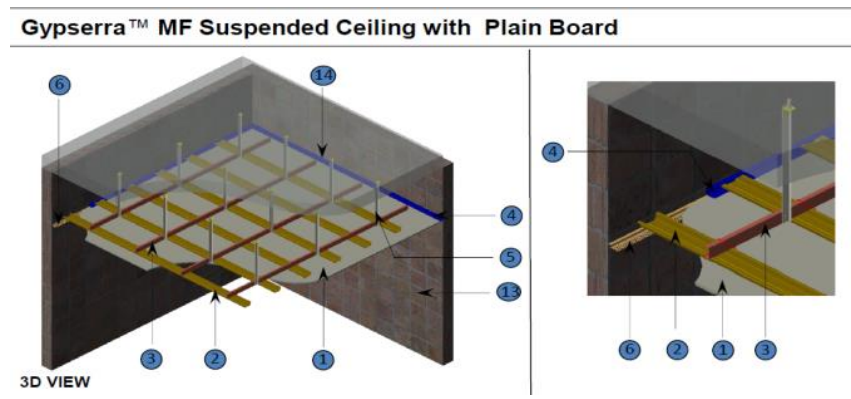

(Source - Gyproc Saint-Gobain grid ceiling specification template)

Gypsum boards have various options and four products are suitable for the hospital construction. The first one is the plain Gypsum board which is the most economical one but the problem is, in case of higher moisture, it may tend to sag. Other options are Moisture resistant (MR) Gypsum boards and Fire and moisture resistant ( FRMR) both have less than 5\% water absorption as per BS 1230. These boards are less prone to moisture absorption and with proper sealing of peripheries, this will be able to meet the criteria of smooth monolithic surface and maintenance of pressure. Sometimes these boards are not selected due to the paper face. Another option in Gypsum board category is, paperless Gypsum boards. These boards don't have paper as liner and the face is glass mat due to which this also acts as a moisture resistant product (less than $5 \%$ water absorption as per BS 1230)

\section{CONCLUSIONS}

As per the design requirement and product performance expectations for negative and positive pressure rooms, grid ceiling in any form may not be an ideal solution until and unless specified by the designer for considering some special performance requirement and the other parameters are taken care of. Though in terms of maintenance and acoustic performance criteria, exposed grid ceilings are the first choice but in defined areas, this may cause pressure loss as well as contamination.

Seamless / joint less / monolithic ceilings are the best options for such type of requirements. If sealed properly in the peripheries with the detailing followed for the installation and sealing of all fixtures which are ceiling mounted are done properly, seamless ceilings are the most appropriate choice to meet the design requirement for the positive and negative pressure room to prevent contamination and pressure loss.
For further precautions, even there can be epoxy or PU coating on the ceiling which will bring resistance against the fumigation and other cleaning methods.

Product evaluation criteria should also be evaluated with the application area performance requirement instead of treating both the things separately.

Future research can be done in the direction of infection spread, hospital acquired infection, morbidity and mortality associated with various false ceiling design and ventilation designs.

\section{REFERENCES}

[1] Judson, s., Prescott, J., \&amp; Munster, V. (2015). Understanding Ebola Virus Transmission. Viruses, 511521.

[2] Bourouiba, L. (2020). Turbulent Gas Clouds and Respiratory Pathogen Emissions: Potential Implications for Reducing Transmission of COVID-19. JAMA.

[3] Kreider JF, Rabl A, Curtiss P. Heating and cooling of buildings: design for efficiency. New York: McGraw-Hill, 1994.

[4] Li, Y. et.al (2007). Role of Ventilation in Airborne Transmission of Infectious Agents in the Built Environement- a Multidisciplinary Systematic Review. Indoor Air, 2-18.

[5] Victorian Advisory Committee. (2007). Guidelines for the Classification and Design of Isolation Rooms in Health Care Facilities on Infection Control. Victoria: Ego.

[6] Qudiesat, K., Elteen, A., Elkarmi, A., Hamad, M., \&amp; Abussaud, M. (2009). Assessment of Airborne Pathogens in Healthcare Settings. AfricanJournal of Microbiology Research, 66-76.

[7] Qudiesat, K., Elteen, A., Elkarmi, A., Hamad, M., \&amp; Abussaud, M. (2009). Assessment of Airborne Pathogens in Healthcare Settings. African Journal of Microbiology Research, 66-76.

[8] Pavelchak, N., DePersis, R., London, M., Stricof, R., Oxtoby, M., DiFerdinando, G., \& Marshall, E. (2000). Identification of Factors That Disrupt Negative Air Pressurization of Respiratory Isolation Rooms. Infect Control Hop Epidemiol.

[9]https://fgiguidelines.org/wpcontent/uploads/2020/03/ASHRAE-COVID-19-guidance20-03-25.pdf. (2020, March 25).Retrieved from fgiguidelines.org:https://fgiguidelines.org/wpontent/uploads/2020/03/ASHRAE-COVID-19-guidance20-03-25.pdf

[10] Gyproc (2016). The White Book. Dublin:Gyproc 